NBER WORKING PAPER SERIES

PERSISTENT EFFECTS OF TEACHER-STUDENT GENDER MATCHES

\author{
Jaegeum Lim \\ Jonathan Meer \\ Working Paper 24128 \\ http://www.nber.org/papers/w24128 \\ NATIONAL BUREAU OF ECONOMIC RESEARCH \\ 1050 Massachusetts Avenue \\ Cambridge, MA 02138 \\ December 2017
}

We are grateful for valuable comments from David Figlio, Mark Hoekstra, Jason Lindo, James West, and seminar participants at Baylor University, Brigham Young University, and the University of Texas. The views expressed herein are those of the authors and do not necessarily reflect the views of the National Bureau of Economic Research.

NBER working papers are circulated for discussion and comment purposes. They have not been peer-reviewed or been subject to the review by the NBER Board of Directors that accompanies official NBER publications.

(C) 2017 by Jaegeum Lim and Jonathan Meer. All rights reserved. Short sections of text, not to exceed two paragraphs, may be quoted without explicit permission provided that full credit, including $(\odot$ notice, is given to the source. 
Persistent Effects of Teacher-Student Gender Matches

Jaegeum Lim and Jonathan Meer

NBER Working Paper No. 24128

December 2017

JEL No. I20

\begin{abstract}
$\underline{\text { ABSTRACT }}$
We exploit data from middle schools in Seoul, South Korea, where students and teachers are randomly assigned to classrooms, and find that female students taught by a female versus a male teacher score higher on standardized tests compared to male students even five years later. We also find that having a female math teacher in 7th grade increases the likelihood that female students take higher-level math courses, aspire to a STEM degree, and attend a STEM-focused high school. These effects are driven by changes in students' attitudes and choices.
\end{abstract}

Jaegeum Lim

Korean National Assembly

Seoul, South Korea

jlim@na.go.kr

Jonathan Meer

Department of Economics

TAMU 4228

College Station, TX 77843

and NBER

jmeer@econmail.tamu.edu 


\title{
Persistent Effects of Teacher-Student Gender Matches
}

\author{
Jaegeum Lim* \\ Korean National Assembly
}

\author{
Jonathan Meer \\ Texas A\&M University \\ and NBER
}

December 7, 2017

\begin{abstract}
We exploit data from middle schools in Seoul, South Korea, where students and teachers are randomly assigned to classrooms, and find that female students taught by a female versus a male teacher score higher on standardized tests compared to male students even five years later. We also find that having a female math teacher in 7 th grade increases the likelihood that female students take higher-level math courses, aspire to a STEM degree, and attend a STEM-focused high school. These effects are driven by changes in students' attitudes and choices.
\end{abstract}

\section{Introduction}

While women have made great strides in fields previously dominated by men, some gender gaps - especially in STEM fields - remain. Lack of female representation can have compounding effects, in which a dearth of role models or general attitudes and expectations discourage female students from entering these fields, making it difficult to increase participation (Leslie et al., 2015; Elbe and $\mathrm{Hu}, 2017)$.

One possible source of these discrepancies may be the interaction of student and teacher gender, in which female students are treated differently by or react differently to female and male teachers. For example, Spencer, Steele and Quinn (1999) show that negative stereotypes of girls' math ability undermine girls' performance on math exams. Most research has focused on contemporaneous effects, namely, how students' current-year outcomes are affected by their current teacher(s).

The results are mixed: many studies find positive and sizable impacts of female teachers on female students (see, for example, Muralidharan and Sheth

\footnotetext{
*Author emails are jlim@na.go.kr and jmeer@tamu.edu. We are grateful for valuable comments from David Figlio, Mark Hoekstra, Jason Lindo, James West, and seminar participants at Baylor University, Brigham Young University, and the University of Texas.
} 
(2016), Dee (2007), and Lim and Meer (forthcoming)), though others do not (Antecol, Eren and Ozbeklik (2015), Holmlund and Sund (2008), and Cho (2012)). Yet the impact on current outcomes is of limited relevance if the effects fade over time. Evidence on longer-run impacts is limited, though indicative that effects can be substantial; Lavy and Sand (2015) find that primary school teachers' bias towards boys can have impacts through high school. ${ }^{1}$ At the higher education level, Carrell, Page and West (2010) find that female cadets at the United States Air Force Academy who are randomly assigned to female instructors for introductory science and math courses are more likely to persist in those fields. ${ }^{2}$

The main issue plaguing identification of the impact of student-teacher gender matches is that, in most contexts, students are not randomly assigned to teachers. This leads to potential confounds in which, for example, female teachers may be systematically assigned to lower-achieving students, or female students who are more likely to succeed with female teachers are assigned to those classrooms. In these cases, any teacher-student gender match effects may reflect sorting rather than, for example, role-model effects. While several of the studies listed above used environments featuring random assignment, there remains little evidence on whether the teacher-student gender match has a long-run impact when taking place at more formative ages - after all, it may be too late to substantially affect field of study by the time a student arrives in college. Further, there is little evidence on the mechanisms through which these effects are operating.

In this paper, we study the longer term effects of teacher-student gender matches at the secondary level. We avoid the problem of nonrandom sorting using a unique Korean middle school practice: the random assignment of students into a classroom each year. Our data track students from 7 th to 12 th grades and enable us to investigate how these effects change over time, as well as how they affect important outcomes like preparation for postsecondary study and choice of major.

We find that the presence of a female teacher substantially increases female students' test scores compared to male students, and this effect persists at least through 12th grade. Our long-lasting gender gap effects are somewhat surprising, since the effects of educational interventions generally fade out fairly quickly (Jacob, Lefgren and Sims, 2010). We show that the mechanism behind these persistent effects appear to be greater focus and participation by female students, as well as selection into higher-quality high schools.

\footnotetext{
${ }^{1} \mathrm{~A}$ related strand of literature shows positive impacts of same-race teachers, particularly for African-American boys (Gershenson et al., 2017; Gershenson, Holt and Papageorge, 2016).

${ }^{2}$ Recent work by Kofoed and McGovney (2017) shows that same-gender and -race role models can influence occupation choice at the United States Military Academy.
} 


\section{Data}

\subsection{Institutional Background}

Several features of the South Korean educational system make it ideally suited to study the impact of teacher-student gender matches. First, elementary school graduates are assigned to a local middle school (spanning 7th to 9th grades) by lottery. ${ }^{3}$ Second, middle school students are randomly assigned to a physical homeroom classroom, through which subject teachers rotate to give lessons. Due to strong social norms and government polices, the goal is to produce homogeneous homeroom classrooms in terms of academic ability (Kang, 2007). The most common approach is to order students by the previous year's academic performance, with the leading student to the first classroom, the second-ranked student to the second classroom, and so on, and schools report adhering to these expectations (Lim and Meer, forthcoming).

Subject teachers are assigned to classrooms in a manner unrelated to the characteristics of either the teachers or the classroom's students. In general, the physical classrooms are split between the subject teachers by, for example, dividing odd- and even-numbered rooms; teacher characteristics are not correlated with student characteristics (Lim and Meer, forthcoming). This quasi-random classroom and teacher assignments produce the random variation in teacher student matching within a school.

Over the past decade, there has been increasing use of ability tracking in South Korea (Byun and Kim, 2010). In our data, ability grouping is common for math and English, but infrequent for Korean. In the presence of ability grouping, the students move to the classroom with their ability group for that subject before returning to their original homeroom classroom. Figure 1 gives an example, with high ability students in Classroom 2 moving to Classroom 1 and low ability students in Classroom 1 moving to Classroom 2 for this subject. This might threaten our identification strategy, which rests on the random assignment of students to teachers. Including school-by-subject fixed effects might be insufficient to account for this potential source of bias. We therefore estimate specifications with school-by-subject-by-ability-group fixed effects, enabling us to compare similar sets of students. In practice, our results are unaffected by the inclusion of finer fixed effects, suggesting that ability grouping does not lead to sorting correlated with teacher-student gender matches and does not bias our results. Our identification thus remains driven by the random assignment of students and teachers to classrooms.

While compulsory education ends in ninth grade, nearly all students in South Korea go on to high school. There are two rounds of admissions to high school in Seoul. Admission is determined through an application process in the first round (Seoul Metropolitan Office of Education, 2012). Students can apply to one of 35 magnet and private autonomous high schools, six art high schools, one athletic

\footnotetext{
${ }^{3}$ While students in some districts can submit a list of schools among which they will be randomly assigned, students in Seoul are not permitted to do so (Korea Legislation Research Institute, 2011).
} 

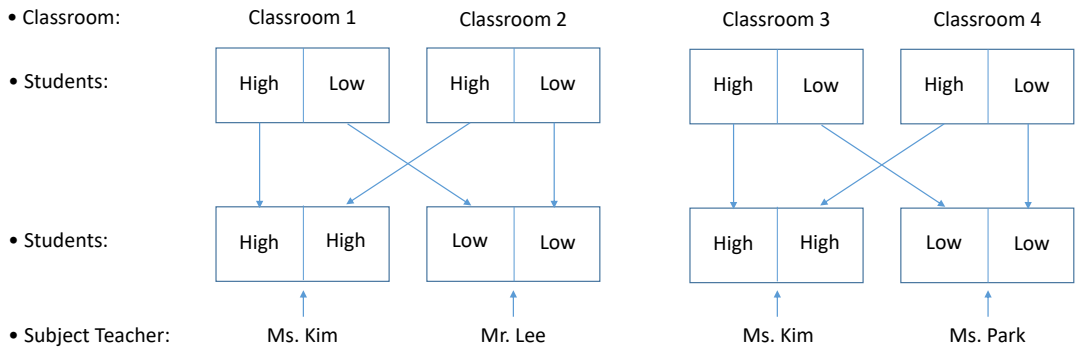

Figure 1: Example of Ability Group Formation

high school, and 74 vocational high schools. Schools select students based on their academic performance and recommendations from principals and teachers. If selected, students must attend the school to which they were admitted.

The second round consists of a lottery for 19 autonomous public high schools, 19 science-focused high schools, 4 art-focused high schools, and 183 general academic high schools. Students can list preferences for one autonomous school, one science- or art-focused school, and up to four general schools. Students receive some preference for schools within their administrative district. The lottery clears entry into the autonomous public and specialized schools first, and then into the general academic high schools. Students are guaranteed entry into a school. Conditional on entering 10th grade, $95.2 \%$ of students in 2011 graduate; only $0.32 \%$ repeat a grade.

One year after high school entry, students choose among academic tracks, irrespective of the type of school. Most schools provide a math-science track and humanities-social science track, excepting specialized science and foreignlanguage schools. Students focus on advanced courses within a given track. Students are free to choose their academic track; past test scores, student characteristics, and so on are not taken into account by the school in restricing a student's choice. Changing tracks is rare; students apply to postsecondary institutions the following year, in twelth grade, and it is difficult to catch up on the requisite coursework. Notably, applying to a STEM department at a postsecondary institution requires scores in advanced math and science courses. Therefore, if teacher-student gender matches in middle school - a particularly formative time period (Berenbaum, Martin and Ruble, 2008) - have persistent effects into high school, they are likely to have lifelong impacts on academic and career choices.

\subsection{Data Set}

Our data set is the Seoul Education Longitudinal Study of 2010 (SELS2010), which surveyed 7th grade students and their teachers in 2010; data are available through 12th grade, with a follow-up survey shortly after high school graduation on postsecondary outcomes. Subject teachers in math, English language, and 
Korean language are linked to the students in 7 th through 10th grades and 12th grade. ${ }^{4}$

Students in the seventh grade panel were sampled by stratified two-stage cluster sample design; first, 74 middle schools were randomly chosen from the population of 370 public or private middle schools in Seoul, excluding two middle schools that are operated by the central government and one athletic middle school. Sixty-two of the sampled schools are coeducational, seven are all-boys, and five are all-girls schools. Two classrooms were then drawn randomly within the sample school. 4,544 of the 5,065 targeted students responded to the survey in 2010. Attrition reduced the sample to 4,347, 4,162, 3,541, 3,394, and 3,305 from 2011 through 2015, respectively; we show later that this attrition does not drive our results. Students in the sample advanced to high school in 2013, with 3,017 going to academic and 524 to vocational high schools. 2,809 and 496 students in academic and vocational high schools remained in the sample through 2015. In May 2016, two months after high school graduation, students were surveyed about their postsecondary outcomes at that point; 2,195 students responded.

Our primary unit of observation is a student-teacher pairing, with multiple observations per student, allowing us to use within-student variation in teacher gender in a given year. Of 13,632 possible student-teacher matches in seventh grade, 3,364 observations cannot be linked due to teacher non-response. An additional 72 observations have missing values in test scores, student gender, and teacher gender. We compare remaining 10,196 observations, representing 4,163 students and 497 teachers, with those that are dropped and find no significant differences between them in students' predetermined characteristics. 1,892 (45.4 percent) students and 408 (82.1 percent) teachers are female. 11 percent of these teacher-student pairs are male-male, 8 percent are male-female, 44 percent are female-male, and 37 percent are female-female.

Student data include standardized test scores for each subject (taking place after the first semester of the school year); we normalize these to have mean of zero and standard deviation of one for ease of interpretation. We also have data on student background characteristics, course-taking in high schools, and track choice, as well as on teacher characteristics including experience and education.

\section{Empirical Approach}

\subsection{Tests of the Identifying Assumptions}

While the institutional characteristics of our setting provide the random variation in teacher-student gender matches necessary for unbiased estimation, it is instructive to examine empirical evidence to validate the identification strategy.

First, we test differences in the characteristics of student-teacher pairings when the teacher is female or male. Panel A of Table 1 presents these results

\footnotetext{
${ }^{4}$ Errors in data collection in eleventh grade mean that those links are not available in that year.
} 
and show no meaningful differences. Panel B compares teacher characteristics by student gender; the only statistically significant difference between the sets of observations is that male students are slightly more likely to have an administrative teacher. As another way to examine whether there are systematic differences in how teachers are assigned to students, we regress teacher gender on students' observable characteristics, controlling for school-by-subject-by-abilitygroup fixed effects. The results are shown in Table 2. Teacher gender is not correlated with students' predetermined characteristics, consistent with random assignment of students to teachers.

Table 1: Comparison of Mean Characteristics

\begin{tabular}{|c|c|c|c|c|}
\hline A. Student Characteristics & $\mathrm{w} / \mathrm{FT}$ & $\mathrm{w} / \mathrm{MT}$ & P-Value & Observations \\
\hline Female Student & $\begin{array}{c}0.46 \\
(0.02)\end{array}$ & $\begin{array}{c}0.42 \\
(0.05)\end{array}$ & 0.37 & 10,258 \\
\hline Married Parents & $\begin{array}{c}0.87 \\
(0.01)\end{array}$ & $\begin{array}{c}0.87 \\
(0.01)\end{array}$ & 0.85 & 10,029 \\
\hline Both Parents Work & $\begin{array}{c}0.47 \\
(0.01)\end{array}$ & $\begin{array}{c}0.46 \\
(0.01)\end{array}$ & 0.20 & 9,984 \\
\hline Family Income & $\begin{array}{l}489.5 \\
(18.7)\end{array}$ & $\begin{array}{l}480.8 \\
(19.5)\end{array}$ & 0.65 & 9,122 \\
\hline Parents w/ B.A. or Higher & $\begin{array}{c}0.56 \\
(0.03)\end{array}$ & $\begin{array}{c}0.58 \\
(0.03)\end{array}$ & 0.67 & 9,427 \\
\hline Attended Prv. Ele. School & $\begin{array}{c}0.06 \\
(0.01)\end{array}$ & $\begin{array}{c}0.06 \\
(0.01)\end{array}$ & 0.60 & 9,991 \\
\hline Number of Siblings & $\begin{array}{c}0.85 \\
(0.01) \\
\end{array}$ & $\begin{array}{c}0.84 \\
(0.02) \\
\end{array}$ & 0.47 & 10,005 \\
\hline \multicolumn{4}{|l|}{ B. Teacher Characteristics } & Observations \\
\hline Female Teacher & $\begin{array}{c}0.83 \\
(0.02)\end{array}$ & $\begin{array}{c}0.80 \\
(0.03)\end{array}$ & 0.38 & 10,258 \\
\hline Graduate Degree & $\begin{array}{c}0.33 \\
(0.03)\end{array}$ & $\begin{array}{c}0.33 \\
(0.03)\end{array}$ & 0.90 & 10,258 \\
\hline Teacher's College & $\begin{array}{c}0.63 \\
(0.03)\end{array}$ & $\begin{array}{c}0.62 \\
(0.03)\end{array}$ & 0.60 & 10,172 \\
\hline Admin Teacher & $\begin{array}{c}0.15 \\
(0.02)\end{array}$ & $\begin{array}{c}0.19 \\
(0.02)\end{array}$ & 0.03 & 10,110 \\
\hline Over Mid Age & $\begin{array}{c}0.56 \\
(0.03)\end{array}$ & $\begin{array}{c}0.57 \\
(0.03)\end{array}$ & 0.43 & 10,170 \\
\hline Teaching less than 5 Yrs & $\begin{array}{c}0.26 \\
(0.03)\end{array}$ & $\begin{array}{c}0.26 \\
(0.03)\end{array}$ & 0.78 & 9,463 \\
\hline
\end{tabular}

Next, we show that subject teachers' characteristics are not correlated with the students' ability and that students are not assigned to physical homeroom classrooms on the basis of their ability. We conduct this exercise for ninth graders in order to use test scores from previous years as a proxy for ability, thus demonstrating that students are not systematically assigned to classrooms 
with male or female teachers based on their previous performance. ${ }^{5}$

Table 2: Likelihood of Having a Female Teacher

\begin{tabular}{|c|c|c|}
\hline & Coefficient & S.E. \\
\hline Female Student & 0.012 & $(0.009)$ \\
\hline Married Parents & 0.003 & $(0.007)$ \\
\hline Family Income & 0.000 & $(0.000)$ \\
\hline At Least One Parent w/ B.A. or Higher & -0.005 & $(0.004)$ \\
\hline Both Parents Work & -0.004 & $(0.005)$ \\
\hline Attended Prv. Ele. School & 0.011 & $(0.010)$ \\
\hline Number of Siblings & 0.004 & $(0.003)$ \\
\hline Observations & 8,422 & \\
\hline$R^{2}$ & 0.798 & \\
\hline
\end{tabular}

We use resampling techniques to examine whether actual classroom assignments appear unusual relative to artificially-constructed classrooms (for more details, see Lehmann and Romano (2005), Good (2006), and Carrell and West (2010)). We randomly draw, without replacement, 10,000 synthetic classrooms from the sample of all students within the school. For each of these synthetic classrooms, we compute total test score of its students. We calculate an empirical p-value measuring the proportion of artificial classrooms with a value greater than the actual classroom in the data. We conduct this exercise using test scores from all three subjects. Under random assignment, the empirical p-values will be uniformly distributed, since any p-value will be observed with equal probability. We test whether the distribution of the empirical p-values is uniform with Kolmogorov-Smirnov and $\chi^{2}$ goodness of fit tests. The results, in Table 3A, show that none of 222 school-by-subject p-value distributions deviate significantly from the uniform distribution at the 5 percent level using the Kolmogorov-Smirnov test; 8 (3.6 percent) do so using the $\chi^{2}$ goodness of fit test. We do not find evidence of nonrandom assignment of students into classrooms by academic ability.

We also check the random assignment of teachers into classrooms with respect to student's academic ability; for each of three test scores, we regress

\footnotetext{
${ }^{5}$ Data on the assignment to physical homeroom classrooms was not available for 7 th and 8th grades, but subject teacher-student linkages are present. Given the nature of random assignment in South Korea, physical classroom assignments are not necessary for our identification strategy.
} 
Table 3: Resampling Tests

\begin{tabular}{|c|c|c|c|}
\hline & Math & $\begin{array}{l}\text { English } \\
\text { Language }\end{array}$ & $\begin{array}{c}\text { Korean } \\
\text { Language }\end{array}$ \\
\hline \multicolumn{4}{|c|}{ A. Test for Student Assignment } \\
\hline $\begin{array}{l}\text { Kolmogorov-Smirnov test } \\
\text { (No. failed / total tests) }\end{array}$ & $0 / 74$ & $0 / 74$ & $0 / 74$ \\
\hline $\begin{array}{l}\chi^{2} \text { goodness of fit test } \\
\text { (No. failed / total tests) }\end{array}$ & $1 / 74$ & $3 / 74$ & $4 / 74$ \\
\hline \multicolumn{4}{|c|}{ B. Test for Teacher Assignment } \\
\hline Female Teacher & $\begin{array}{r}-0.010 \\
(0.040)\end{array}$ & $\begin{array}{c}-0.034 \\
(0.068)\end{array}$ & $\begin{array}{r}-0.016 \\
(0.047)\end{array}$ \\
\hline Graduate School Degree & $\begin{array}{c}-0.060 \\
(0.037)\end{array}$ & $\begin{array}{r}-0.041 \\
(0.043)\end{array}$ & $\begin{array}{r}-0.055 \\
(0.038)\end{array}$ \\
\hline Full Time Teacher & $\begin{array}{c}-0.005 \\
(0.049)\end{array}$ & $\begin{array}{c}0.054 \\
(0.055)\end{array}$ & $\begin{array}{c}-0.064 \\
(0.069)\end{array}$ \\
\hline Administrative Teacher & $\begin{array}{c}0.045 \\
(0.047)\end{array}$ & $\begin{array}{r}-0.005 \\
(0.069)\end{array}$ & $\begin{array}{c}0.039 \\
(0.045)\end{array}$ \\
\hline Observations & 591 & 621 & 603 \\
\hline \multicolumn{4}{|c|}{$\begin{array}{l}\text { Notes: Each column represents a separate regression. Dependent variable is the empirical p-value } \\
\text { from resampling, for three test scores. Independent variables are teacher gender, dummies for } \\
\text { graduate degree, full time teacher, and administrative teacher. Each specification controls for } \\
\text { school fixed effects. Standard errors in parentheses are clustered at school level. The Kolmogorov } \\
\text { Smirnov and } \chi^{2} \text { goodness of fit test results indicate the number of tests of the uniformity of the } \\
\text { distribution of p-values that failed at the } 5 \text { percent level. } \\
{ }^{*} p<0.10,{ }^{* *} p<0.05,{ }^{* * *} p<0.01\end{array}$} \\
\hline
\end{tabular}

the empirical p-values on average characteristics of teachers visiting the classroom, controlling for school fixed effects to accommodate the random assignment within a school. As is shown in Table 3B, none of 24 coefficients is statistically significant at the 10 percent level. Therefore, there is little evidence of nonrandom assignment of teachers into classrooms in terms of student's academic ability.

\subsection{Specification}

Our estimation strategy is straightforward. First, we examine contemporaneous effects of teacher-student gender matches by estimating a series of specifications with the following general form:

$$
y_{i j b g s}=\beta_{0}+\beta_{1} f s_{i}+\beta_{2} f t_{j}+\beta_{3} f s_{i} f t_{j}+X_{i} \delta_{1}^{\prime}+T_{j} \delta_{2}^{\prime}+\gamma_{b g s}+\varepsilon_{i j b g s},
$$

where $y_{i j b g s}$ is a test score of student $i$ taught by teacher $j$ for subject $b$ in ability group level $g$, if any, in 7 th grade at school $s . f s_{i}$ and $f t_{j}$ are indicator 
variables equaling one if student $i$ and subject teacher $j$ are female, respectively. Our simplest specification includes only these variables. We add, in turn, an increasingly rich set of controls. These include $X_{i}$, a vector of students' predetermined characteristics including income, the number of siblings, andindicators for living with both parents, having at least one parent with bachelor's degree or higher, having both parents being employed, and $T_{j}$, a vector of teacher characteristics, including teacher's age and indicators for teacher graduating from teacher's school, teacher with master's degree, homeroom teacher, the teacher holding an administrative position, and the teaching having less than 5 years of experience. We include school by subject by ability group level fixed effects $\gamma_{b g s}$ to compare students of the same ability in a subject within a school, to ensure that ordinary least squares (OLS) produces unbiased estimates. Standard errors are clustered at the school level to account for correlations among students within the same schools. If the random assignment suggested by the institutional features truly holds, these specifications should not differ substantially when the additional controls are included.

$\beta_{1}$ is the difference in average academic achievement between female and male students when taught by a male teacher. $\beta_{2}$ represents the average difference in performance for male students between being taught by a female teacher and being taught by a male teacher. $\beta_{3}$ indicates the change in the gender gap between female and male students when switching from a male to a female teacher.

We modify Equation 1 slightly to examine the effects of teacher-student gender matches in 7 th grade on standardized test scores over time:

$$
y_{i j b g t s}=\beta_{0}+\beta_{1} f s_{i}+\beta_{2} f t_{j}+\beta_{3} f s_{i} f t_{j}+\gamma_{b g s}+\varepsilon_{i j b g t s},
$$

where $y_{i j b g t s}$ is test score in year $t=2$ through 6 (namely, 8th through 12 th grades), which is normalized within a subject and the year. We focus on the effects of 7 th grade teachers over time because we are most confident that random assignment holds for that grade. Students are entering a randomlyassigned middle school and their academic performance cannot yet have been affected by teachers at the middle school when assigned to 7th-grade classrooms. This also provides the longest time span to examine the persistence of these effects.

Our primary interest is the coefficient $\beta_{3}$ when $t=2$ through 6 , representing gender gap effects one through five years after exposure to the 7 th grade teacher. When we examine outcomes that do not differ across subject, such as choice of academic track, we collapse this specification to a single observation per student.

\section{Results}

\subsection{Contemporaneous Effects}

We begin by examining the effect of teacher-student gender matches in 7 th grade on students' standardized test scores in that year. Table 4 begins with the most 
parsimonious specification that includes no additional controls. The coefficient on the female student $\times$ female teacher indicator in Column (1) indicates that the performance gap between female and male students increases by $13.9 \%$ of a standard deviation (s.e. $=6.1 \%$ ) when the teacher is female rather than male. This effect consists of a statistically insignificant decrease in boys' performance of 0.06 standard deviations and an increase in girls' performance of 0.07 . In other words, the gender gap effect is composed of an opposite-gender teacher effect for switching from a male teacher to a female one for male students $\left(-\beta_{2}\right)$ and a same-gender teacher effect for the switch to a female teacher for female students $\left(\beta_{2}+\beta_{3}\right)$. This effect is substantial, considering the evidence that 10 additional days of schooling increases academic performance by 0.01 standard deviation (Carlsson et al., 2015). Adding controls across specifications does not meaningfully affect the estimate of this gender gap effect, providing additional evidence that random assignment holds in our data. Note, though, that the share of the gender gap effect attributable to changes in boys' performance does change. Boys no longer see a negative impact of switching to a female teacher by Column (3), but the estimates of $\beta_{2}$ are noisy throughout.

Even the inclusion of student and teacher fixed effects in Columns (6) and (7), thus identifying from within-student and within-teacher variation in the gender match, leaves the gender gap effect intact. Taken together, these results indicate that the teacher-student gender match is uncorrelated with observable and unobservable student and teacher characteristics. These findings replicate those using other South Korean data to examine same-year effects (Lim and Meer, forthcoming). ${ }^{6}$

\subsection{Longer Term Effects}

Table 5 presents the impacts of the 7th grade teacher-student gender match for later years. Panel A presents results including school-by-subject-by-abilitygroup fixed effects and Panel B also includes student and teacher fixed effects (corresponding to Columns (3) and (7), respectively, of Table 4). For brevity, we limit ourselves to the most parsiminious specification that we believe clearly satisfies the identifying assumptions (Panel A), but also present the most restrictive (Panel B).

Somewhat surprisingly, we find that the gender gap effects persist even five years after the initial teacher-student gender match. The effects vary slightly over time, but there are no significant differences between the contemporaneous effect and the effects in the following years. ${ }^{7}$ While education interventions are generally characterized by large fade-out effects (Jacob, Lefgren and Sims, 2010), previous studies on longer-run impacts of teacher gender suggest that the

\footnotetext{
${ }^{6}$ That paper uses data on ninth graders throughout South Korea in 2004 and finds a contemporaneous interaction effect of female students with female teachers of about 0.10.

${ }^{7}$ In Panel A, the p-values are $p=0.98, p=0.91, p=0.75, p=0.59$, and $p=0.68$ for the differences between the interaction coefficients in Columns (1)-(5) and that in Column (3) of Table 4, respectively. In Panel B, p-values are $p=0.82, p=0.79, p=0.55, p=0.99$, and $p=0.48$ for the differences between the interaction coefficients in Columns (1)-(5) and Column (7) of Table 4
} 
Table 4: Contemporaneous Effects in 7th Grade

\begin{tabular}{|c|c|c|c|c|c|c|c|}
\hline & (1) & $(2)$ & (3) & $(4)$ & $(5)$ & $(6)$ & $(7)$ \\
\hline FS & $\begin{array}{c}0.028 \\
(0.055)\end{array}$ & $\begin{array}{c}0.088 \\
(0.057)\end{array}$ & $\begin{array}{c}0.050 \\
(0.042)\end{array}$ & $\begin{array}{c}0.035 \\
(0.049)\end{array}$ & $\begin{array}{c}0.059 \\
(0.054)\end{array}$ & & \\
\hline FT in 7th Grade & $\begin{array}{c}-0.061 \\
(0.075)\end{array}$ & $\begin{array}{c}-0.064 \\
(0.114)\end{array}$ & $\begin{array}{c}0.023 \\
(0.071)\end{array}$ & $\begin{array}{c}0.009 \\
(0.074)\end{array}$ & $\begin{array}{c}0.035 \\
(0.095)\end{array}$ & $\begin{array}{c}-0.041 \\
(0.108)\end{array}$ & \\
\hline $\mathrm{FS} \times \mathrm{FT}$ in 7 th Grade & $\begin{array}{c}0.139^{* *} \\
(0.061)\end{array}$ & $\begin{array}{l}0.148^{* *} \\
(0.064)\end{array}$ & $\begin{array}{l}0.147^{\text {*** }} \\
(0.047)\end{array}$ & $\begin{array}{l}0.161^{* * *} \\
(0.054)\end{array}$ & $\begin{array}{c}0.145^{* *} \\
(0.059)\end{array}$ & $\begin{array}{c}0.185^{* *} \\
(0.080)\end{array}$ & $\begin{array}{l}0.190^{* * *} \\
(0.068)\end{array}$ \\
\hline $\begin{array}{l}\text { Observations } \\
R^{2}\end{array}$ & $\begin{array}{r}10,196 \\
0.006\end{array}$ & $\begin{array}{r}10,196 \\
0.171\end{array}$ & $\begin{array}{r}10,047 \\
0.388\end{array}$ & $\begin{array}{l}8,369 \\
0.399\end{array}$ & $\begin{array}{l}7,521 \\
0.384\end{array}$ & $\begin{array}{l}9,026 \\
0.824\end{array}$ & $\begin{array}{r}10,047 \\
0.819\end{array}$ \\
\hline $\begin{array}{l}\text { Sch } \times \text { Sbj FEs } \\
\text { Sch } \times \text { Sbj } \times \text { Abg FEs } \\
\text { Student Controls } \\
\text { Teacher Controls } \\
\text { Student FEs } \\
\text { Teacher FEs }\end{array}$ & & Yes & Yes & $\begin{array}{l}\text { Yes } \\
\text { Yes }\end{array}$ & $\begin{array}{l}\text { Yes } \\
\text { Yes } \\
\text { Yes }\end{array}$ & $\begin{array}{l}\text { Yes } \\
\text { Yes }\end{array}$ & $\begin{array}{l}\text { Yes } \\
\text { Yes }\end{array}$ \\
\hline \multicolumn{8}{|c|}{$\begin{array}{l}\text { Notes: Each column shows results from a separate regression with normalized seventh grade test score } \\
\text { as the dependent variable. Student controls include family income, number of siblings, and indicators for } \\
\text { parents living together, both parents working, at least one parent having college degree or higher, and } \\
\text { the student having attended a private elementary school. Teacher controls include indicators for having } \\
\text { less than five years' experience, graduating from a teachers' school, having a graduate degree, having } \\
\text { administrative teacher responsibility, and being less than age of } 40 \text {. In Columns } 6 \text { and } 7 \text {, female student } \\
\text { and female teacher dummies are subsumed by student fixed effects and teacher fixed effects, respectively. } \\
\text { Standard errors in parentheses are clustered at school level. } \\
{ }^{*} p<.10,{ }^{* *} p<.05,{ }^{* * *} p<.01\end{array}$} \\
\hline
\end{tabular}

impacts of this particular phenomenon may be long-lasting (Carrell, Page and West, 2010; Lavy and Sand, 2015).

STEM outcomes are of particular interest, since although the gender gap in math achievement in secondary education is small, women are substantially underrepresented in both STEM majors and careers. Column (1) of Table 6 presents the results for the effects of 7th grade subject teachers on student's math-science track choice in 11th grade. These specifications include fixed effects for school by subject and 7th grade ability group, which should adequately control for any possible nonrandom assignment to ability group in 7th grade. There are no significant gender gap effects for any subjects; however, there is a statistically significant same-gender teacher effect for female students. Girls who had a 7 th grade math teacher are 15.1 percentage points $($ s.e. $=7.5)$ more likely to choose the math-science track in high school when taught by female versus male math teacher (the combination of having a female math teacher and the additional effect of female math teachers on girls). Substantial gender gap effects emerge in advanced math coursetaking in 11th grade (Column 2), with having a female 7 th grade math teacher reducing the gender gap between female and male students by 9.7 percentage points $($ s.e. $=5.5)$. The same gender teacher effect for female student is even bigger; female students are 15.7 percentage points $($ s.e. $=6.6)$ more likely to take at least one advanced math 
Table 5: Effects over Time

\begin{tabular}{|c|c|c|c|c|c|}
\hline & \multicolumn{5}{|c|}{ Dep. Var. = Standardized Test Scores in } \\
\hline & $\begin{array}{l}\text { 8th Grade } \\
\text { (1) }\end{array}$ & $\begin{array}{l}\text { 9th Grade } \\
(2)\end{array}$ & $\begin{array}{l}\text { 10th Grade } \\
(3)\end{array}$ & $\begin{array}{l}\text { 11th Grade } \\
\text { (4) }\end{array}$ & $\begin{array}{c}\text { 12th Grade } \\
(5)\end{array}$ \\
\hline \multicolumn{6}{|c|}{ A. Controls for $S c h \times S b j \times G r p F E s$} \\
\hline FS & $\begin{array}{c}0.078 \\
(0.062)\end{array}$ & $\begin{array}{c}0.067 \\
(0.065)\end{array}$ & $\begin{array}{c}0.051 \\
(0.057)\end{array}$ & $\begin{array}{c}0.093 \\
(0.061)\end{array}$ & $\begin{array}{c}0.020 \\
(0.063)\end{array}$ \\
\hline FT in 7th Grade & $\begin{array}{c}-0.078 \\
(0.069)\end{array}$ & $\begin{array}{c}-0.126^{* *} \\
(0.060)\end{array}$ & $\begin{array}{c}-0.081 \\
(0.071)\end{array}$ & $\begin{array}{c}-0.051 \\
(0.073)\end{array}$ & $\begin{array}{c}-0.027 \\
(0.080)\end{array}$ \\
\hline $\mathrm{FS} \times \mathrm{FT}$ in 7 th Grade & $\begin{array}{l}0.145^{* *} \\
(0.065)\end{array}$ & $\begin{array}{c}0.140^{*} \\
(0.070)\end{array}$ & $\begin{array}{c}0.125^{*} \\
(0.065)\end{array}$ & $\begin{array}{c}0.104 \\
(0.066)\end{array}$ & $\begin{array}{l}0.177^{* *} \\
(0.073)\end{array}$ \\
\hline $\begin{array}{l}\text { Observations } \\
R^{2}\end{array}$ & $\begin{array}{l}9,653 \\
0.326\end{array}$ & $\begin{array}{l}9,232 \\
0.236\end{array}$ & $\begin{array}{l}7,497 \\
0.174\end{array}$ & $\begin{array}{l}7,376 \\
0.168\end{array}$ & $\begin{array}{l}7,119 \\
0.121\end{array}$ \\
\hline \multicolumn{6}{|c|}{ B. Controls for $S c h \times S b j \times$ Grp FEs, Stu FEs, \& Tch FEs } \\
\hline FS $\times$ FT in 7 th Grade & $\begin{array}{l}0.175^{* *} \\
(0.061)\end{array}$ & $\begin{array}{c}0.169 \\
(0.105)\end{array}$ & $\begin{array}{c}0.131 \\
(0.106)\end{array}$ & $\begin{array}{c}0.192^{*} \\
(0.104)\end{array}$ & $\begin{array}{l}0.259^{* *} \\
(0.101)\end{array}$ \\
\hline $\begin{array}{l}\text { Observations } \\
R^{2}\end{array}$ & $\begin{array}{l}9,653 \\
0.818\end{array}$ & $\begin{array}{l}9,232 \\
0.691\end{array}$ & $\begin{array}{l}7,497 \\
0.593\end{array}$ & $\begin{array}{l}7,376 \\
0.704\end{array}$ & $\begin{array}{l}7,119 \\
0.553\end{array}$ \\
\hline \multicolumn{6}{|c|}{$\begin{array}{l}\text { Notes: Each column shows results from a separate regression. Dependent variables in Columns } 1 \text { through } 5 \text { are } \\
\text { normalized test scores within a subject and a year, in } 8 \text { th through } 12 \text { th grades, respectively. Panel A controls for } \\
7 \text { th grade school by subject by } 7 \text { th grade ability group level fixed effects and Panel B adds } 7 \text { th grade student fixed } \\
\text { effects and } 7 \text { th grade teacher fixed effects. In Panel B, female student and female teacher dummies are subsumed } \\
\text { by student fixed effects and teacher fixed effects, respectively. Standard errors in parentheses are clustered at school } \\
\text { level. } \\
{ }^{*} p<.10,{ }^{* *} p<.05,{ }^{* * *} p<.01\end{array}$} \\
\hline
\end{tabular}

course when they were taught by female math teacher in 7 th grade versus a male teacher. Column (3) shows the impacts on self-reported interest in majoring in a STEM field; once again, having a female 7th grade math teacher substantially reduces the male-female gap in these aspirations. Similarly, Column (4) shows that the male-female gap in attending a STEM-focused high school is substantially reduced when a female student has a female math teacher in 7th grade. Especially given the baseline means, listed in the bottom of line of the table, these effects are quite meaningful. Finally, Column (5) reports the impact on the likelihood that a student reports that they have no set plans for postsecondary education; female students are significantly less likely to report that they have no such plans if they had female teachers in any subject in 7th grade. This provides further evidence of an overall positive influence of female teachers on female students, which we turn to in the next section.

\subsection{Evidence on Mechanisms}

Altogether, these results show dramatic impacts of having female teachers on female students in the long run, with substantial increases in preparation for postsecondary STEM study. We examine several possible drivers of these results. 
Table 6: Effects on STEM Outcomes

\begin{tabular}{|c|c|c|c|c|c|}
\hline & $\begin{array}{l}(1) \\
\text { Math } \\
\text { Track }\end{array}$ & $\begin{array}{c}(2) \\
\text { Advanced } \\
\text { Math }\end{array}$ & $\begin{array}{c}(3) \\
\text { Plan } \\
\text { STEM }\end{array}$ & $\begin{array}{c}(4) \\
\text { STEM } \\
\text { School }\end{array}$ & $\begin{array}{c}(5) \\
\text { No Plan }\end{array}$ \\
\hline FS & $\begin{array}{r}-0.177 \\
(0.108)\end{array}$ & $\begin{array}{c}-0.038 \\
(0.106)\end{array}$ & $\begin{array}{c}-0.124 \\
(0.158)\end{array}$ & $\begin{array}{r}-0.143 \\
(0.107)\end{array}$ & $\begin{array}{c}0.137^{*} \\
(0.075)\end{array}$ \\
\hline Math FT in 7th Grade & $\begin{array}{c}0.100 \\
(0.069)\end{array}$ & $\begin{array}{c}0.060 \\
(0.053)\end{array}$ & $\begin{array}{c}0.031 \\
(0.088)\end{array}$ & $\begin{array}{c}-0.041 \\
(0.033)\end{array}$ & $\begin{array}{r}0.076^{*} \\
(0.040)\end{array}$ \\
\hline Eng FT in 7 th Grade & $\begin{array}{r}-0.019 \\
(0.118)\end{array}$ & $\begin{array}{c}0.196 \\
(0.138)\end{array}$ & $\begin{array}{r}-0.115 \\
(0.168)\end{array}$ & $\begin{array}{c}-0.018 \\
(0.033)\end{array}$ & $\begin{array}{c}0.128 \\
(0.087)\end{array}$ \\
\hline Kor FT in 7 th Grade & $\begin{array}{c}0.096 \\
(0.080)\end{array}$ & $\begin{array}{r}-0.014 \\
(0.068)\end{array}$ & $\begin{array}{c}0.146 \\
(0.092)\end{array}$ & $\begin{array}{c}0.022 \\
(0.064)\end{array}$ & $\begin{array}{c}0.054 \\
(0.042)\end{array}$ \\
\hline FS $\times$ Math FT in 7 th Grade & $\begin{array}{c}0.051 \\
(0.060)\end{array}$ & $\begin{array}{r}0.097^{*} \\
(0.055)\end{array}$ & $\begin{array}{c}0.146^{*} \\
(0.080)\end{array}$ & $\begin{array}{c}0.073^{*} \\
(0.040)\end{array}$ & $\begin{array}{r}-0.065^{*} \\
(0.034)\end{array}$ \\
\hline FS $\times$ Eng FT in 7 th Grade & $\begin{array}{r}-0.008 \\
(0.068)\end{array}$ & $\begin{array}{c}-0.203^{* *} \\
(0.080)\end{array}$ & $\begin{array}{r}-0.082 \\
(0.121)\end{array}$ & $\begin{array}{r}-0.006 \\
(0.035)\end{array}$ & $\begin{array}{r}-0.100^{*} \\
(0.053)\end{array}$ \\
\hline FS $\times$ Kor FT in 7 th Grade & $\begin{array}{r}-0.068 \\
(0.084)\end{array}$ & $\begin{array}{c}0.056 \\
(0.074)\end{array}$ & $\begin{array}{r}-0.116 \\
(0.096)\end{array}$ & $\begin{array}{c}0.072 \\
(0.089)\end{array}$ & $\begin{array}{r}-0.096^{*} \\
(0.056)\end{array}$ \\
\hline Observations & 1,635 & 1,456 & 1,043 & 1,721 & 1,640 \\
\hline$R^{2}$ & 0.229 & 0.248 & 0.280 & 0.252 & 0.267 \\
\hline Dep. Var. Mean & 0.351 & 0.201 & 0.357 & 0.081 & 0.096 \\
\hline \multicolumn{6}{|c|}{$\begin{array}{l}\text { Each column represents a separate regression, controlling for school by math ability group by English ability } \\
\text { group by Korean ability group in } 7 \text { th grade fixed effects. Dependent variables are indicators for the choice } \\
\text { of the math-science track in 11th grade, taking at least one advanced math course required for admission } \\
\text { to a STEM postsecondary degree program, self-reporting the desire to seek a STEM postsecondary degree } \\
\text { conditional on having decided a major, attending a STEM-oriented high school, and having no postsecondary } \\
\text { plans. Standard errors in parentheses are clustered at school level. } \\
{ }^{*} p<.10,{ }^{* *} p<.05,{ }^{* * *} p<.01\end{array}$} \\
\hline
\end{tabular}

We begin by examining whether female students taught by a female teacher are more likely to be taught by a female teacher in later years. In that case, the persistent effects of 7 th grade teachers could, in fact, be driven by cumulative effects of later teachers. As seen in Table 7, our results are not driven by cumulative exposure to female teachers set in motion by better performance in 7 th grade.

We next examine whether teacher-student gender matches in 7 th grade affects ability group assignment in later years. Table 8 shows results for the likelihood of being in a high ability group in 8th through 10th and 12th grades in a given subject. While this potential mechanism has a reasonable basis better performance in 7th grade leads to higher ability grouping in later years, with better performance in those years - we find no evidence that this is driving our results.

Finally, we examine whether attrition from the sample is likely to bias our results. If attrition is systematically related to the teacher-student gender interaction - if low-performing female students with female teachers are more likely 
Table 7: Effects on Future Teacher Gender

\begin{tabular}{lcccc}
\hline & \multicolumn{4}{c}{ Dep. Var. $=$ Likelihood of Having Female Teacher in } \\
\cline { 2 - 5 } & $\begin{array}{c}\text { 8th Grade } \\
(1)\end{array}$ & $\begin{array}{c}9 \text { th Grade } \\
(2)\end{array}$ & $\begin{array}{c}\text { 10th Grade } \\
(3)\end{array}$ & $\begin{array}{c}12 \text { th Grade } \\
(4)\end{array}$ \\
\hline FS & 0.026 & -0.016 & $0.198^{* * *}$ & $0.174^{* * *}$ \\
& $(0.023)$ & $(0.018)$ & $(0.040)$ & $(0.054)$ \\
FT in 7th Grade & 0.034 & $-0.039^{*}$ & 0.046 & -0.026 \\
& $(0.027)$ & $(0.022)$ & $(0.038)$ & $(0.037)$ \\
FS $\times$ FT in 7th Grade & -0.021 & 0.020 & -0.041 & -0.020 \\
& $(0.024)$ & $(0.019)$ & $(0.039)$ & $(0.047)$ \\
\hline Observations & 9,660 & 7,736 & 6,825 & 5,720 \\
$R^{2}$ & 0.475 & 0.545 & 0.170 & 0.174 \\
Dep. Var. Mean & 0.837 & 0.802 & 0.542 & 0.470 \\
\hline $\begin{array}{l}\text { Notes: Each column represents a separate regression, controlling for } 7 \text { th grade school by subject by 7th } \\
\text { grade ability group level fixed effects. Dependent variables in Columns 1 through 4 are indicators for having }\end{array}$ \\
a female teacher in 8th, 9th, 10th and 12th grades. Standard errors in parentheses are clustered at school \\
level. \\
${ }^{*} p<.10,{ }^{* *} p<.05,{ }^{* * *} p<.01$
\end{tabular}

Table 8: Effect on Ability Grouping

\begin{tabular}{lcccc}
\hline & \multicolumn{3}{c}{ Dep. Var. $=$ Likelihood of Being in High Ability Group in } \\
\cline { 2 - 5 } & $\begin{array}{c}\text { 8th Grade } \\
(1)\end{array}$ & $\begin{array}{c}\text { th Grade } \\
(2)\end{array}$ & $\begin{array}{c}10 \text { th Grade } \\
(3)\end{array}$ & $\begin{array}{c}12 \text { th Grade } \\
(4)\end{array}$ \\
\hline FS & -0.008 & 0.012 & $-0.062^{* *}$ & -0.010 \\
& $(0.016)$ & $(0.013)$ & $(0.031)$ & $(0.019)$ \\
FT in 7th Grade & -0.010 & -0.014 & -0.032 & -0.014 \\
& $(0.023)$ & $(0.013)$ & $(0.030)$ & $(0.017)$ \\
FS $\times$ FT in 7th Grade & 0.008 & -0.001 & 0.042 & -0.004 \\
& $(0.017)$ & $(0.014)$ & $(0.030)$ & $(0.014)$ \\
\hline Observations & 6,229 & 5,975 & 6,968 & 5,664 \\
$R^{2}$ & 0.598 & 0.679 & 0.241 & 0.142 \\
Dep. Var. Mean & 0.279 & 0.139 & 0.194 & 0.038 \\
\hline $\begin{array}{l}\text { Notes: Each column represents a separate regression, controlling for } 7 \text { th grade school by subject by } 7 \text { th } \\
\text { grade ability group fixed effects. The response variables for Columns 1 through 4 are indicators for being in }\end{array}$ \\
a high ability group level in 8th, 9th, 10th and 12th grades, respectively. Standard errors in parentheses are \\
clustered at school level. \\
${ }^{*} p<.10,{ }^{* *} p<.05,{ }^{* * *} p<.01$
\end{tabular}

to exit the sample - our results would be the product of a selected sample. In Table 9, we test whether the proportion of female teachers in 7th grade impacts the likelihood of attriting from the sample. No meaningful patterns emerge that indicate that selective attrition drives our results. Further, recreating our primary results in Tables 1 and 2 using only students who remained in the sample all five years yields similar results.

Having addressed these possibilities, we turn to student attitudes and choices. 
Table 9: Attrition

\begin{tabular}{|c|c|c|c|c|c|c|}
\hline & \multicolumn{6}{|c|}{ Dep. Var. = Likelihood of Attrition in } \\
\hline & $\begin{array}{l}\text { 8th } \\
\text { Grade } \\
(1)\end{array}$ & $\begin{array}{l}\text { 9th } \\
\text { Grade } \\
(2)\end{array}$ & $\begin{array}{l}\text { 10th } \\
\text { Grade } \\
(3)\end{array}$ & $\begin{array}{c}11 \text { th } \\
\text { Grade } \\
(4)\end{array}$ & $\begin{array}{l}12 \text { th } \\
\text { Grade } \\
(5)\end{array}$ & $\begin{array}{c}\text { Post } \\
\text { Secondary } \\
(6)\end{array}$ \\
\hline FS & $\begin{array}{c}-0.009 \\
(0.026)\end{array}$ & $\begin{array}{c}0.052 \\
(0.052)\end{array}$ & $\begin{array}{c}0.035 \\
(0.083)\end{array}$ & $\begin{array}{c}-0.032 \\
(0.049)\end{array}$ & $\begin{array}{c}-0.006 \\
(0.029)\end{array}$ & $\begin{array}{c}-0.055 \\
(0.133)\end{array}$ \\
\hline Pct. FTs in 7th Grade & $\begin{array}{c}0.038 \\
(0.036)\end{array}$ & $\begin{array}{c}-0.041 \\
(0.045)\end{array}$ & $\begin{array}{c}0.092 \\
(0.120)\end{array}$ & $\begin{array}{c}-0.077 \\
(0.070)\end{array}$ & $\begin{array}{c}0.074 \\
(0.063)\end{array}$ & $\begin{array}{c}0.006 \\
(0.188)\end{array}$ \\
\hline $\begin{array}{l}\text { FS } \times \\
\text { Pct. FTs in } 7 \text { th Grade }\end{array}$ & $\begin{array}{c}0.014 \\
(0.029)\end{array}$ & $\begin{array}{c}-0.053 \\
(0.063)\end{array}$ & $\begin{array}{c}-0.108 \\
(0.105)\end{array}$ & $\begin{array}{c}0.034 \\
(0.059)\end{array}$ & $\begin{array}{c}-0.031 \\
(0.039)\end{array}$ & $\begin{array}{c}0.092 \\
(0.171)\end{array}$ \\
\hline $\begin{array}{l}\text { Observations } \\
R^{2}\end{array}$ & $\begin{array}{l}2,292 \\
0.114\end{array}$ & $\begin{array}{l}2,204 \\
0.186\end{array}$ & $\begin{array}{l}2,113 \\
0.293\end{array}$ & $\begin{array}{l}1,721 \\
0.196\end{array}$ & $\begin{array}{l}1,671 \\
0.185\end{array}$ & $\begin{array}{l}1,647 \\
0.188\end{array}$ \\
\hline \multicolumn{7}{|c|}{$\begin{array}{l}\text { Each column represents a separate regression, controlling for school by math ability group } \times \text { English ability group } \times \\
\text { Korean ability group in } 7 \text { th grade fixed effects. The dependent variables for Columns } 1 \text { through } 6 \text { are, respectively, } \\
\text { indicators for a student attriting from the sample in } 8 \text { th through } 12 \text { th grades and post secondary period. The percent } \\
\text { female teachers is defined the proportion of females in three subject of math, English, and Korean, conditional on } \\
\text { no missing values in teacher gender. Standard errors in parentheses are clustered at school level. } \\
{ }^{*} p<.10,{ }^{* *} p<.05,{ }^{* * *} p<.01\end{array}$} \\
\hline
\end{tabular}

Indeed, our results appear to be driven by changes in student attitudes, which result in female students who had female teachers in 7 th grade being more likely to select higher-quality high schools. Column (5) of Table 6 shows that having female teachers in 7 th grade increases the likelihood that female students declare that they have postsecondary plans. In Table 10, we show the impact of the female student-female teacher match on an index of self-reported student engagement constructed using principal component analysis. While female students have a lower engagement score than male students, having a female teacher in a particular subject in 7th grade eliminates this gap, and the effects persist into high school. The point estimates lose statistical significance by 11th grade, but remain relatively large.

Given the nature of the high school application process in Seoul, any increase in high school quality necessarily reflects student preferences to a great degree. In Table 12, we show the impact of the 7 th grade teacher-student gender match on the quality of the student's classroom peers, as estimated by previous-year standardized test scores, and on teacher value-added. ${ }^{8}$ Given the random assignment in middle schools, it is reassuring that there are no effects in 8th and 9th grades. However, in 10th grade - high school - female students who had a female teacher in 7th grade have both peers and teachers who are significantly higher quality as measured by test scores, and this effect is also present in 12 th grade. $^{9}$

\footnotetext{
${ }^{8}$ We calculate value added by estimating teacher fixed effects from a regression of leave-out mean scores in grade $g$ on leave-out mean scores in grade $g-1$ and school-by-subject-byability-group fixed effects.

${ }^{9}$ Due to the data limitations discussed in Section 2.2 , we are unable to estimate these results for 11th grade.
} 
Table 10: Effects on Student Engagement Index

\begin{tabular}{|c|c|c|c|c|c|c|}
\hline & \multicolumn{6}{|c|}{ Dep. Var. = Student Mechanism Index in } \\
\hline & $\begin{array}{c}7 \text { th } \\
\text { Grade } \\
(1)\end{array}$ & $\begin{array}{c}\text { 8th } \\
\text { Grade } \\
(2)\end{array}$ & $\begin{array}{c}9 \text { th } \\
\text { Grade } \\
(3)\end{array}$ & $\begin{array}{c}10 \text { th } \\
\text { Grade } \\
(4)\end{array}$ & $\begin{array}{c}11 \text { th } \\
\text { Grade } \\
(5)\end{array}$ & $\begin{array}{c}12 \text { th } \\
\text { Grade } \\
(6)\end{array}$ \\
\hline FS & $\begin{array}{c}-0.106^{* * *} \\
(0.035)\end{array}$ & $\begin{array}{c}-0.084^{* *} \\
(0.040)\end{array}$ & $\begin{array}{c}-0.117^{* *} \\
(0.058)\end{array}$ & $\begin{array}{r}-0.101^{*} \\
(0.052)\end{array}$ & $\begin{array}{c}-0.045 \\
(0.074)\end{array}$ & $\begin{array}{r}-0.055 \\
(0.074)\end{array}$ \\
\hline FT in 7 th Grade & $\begin{array}{c}0.000 \\
(0.052)\end{array}$ & $\begin{array}{c}0.031 \\
(0.070)\end{array}$ & $\begin{array}{c}-0.051 \\
(0.055)\end{array}$ & $\begin{array}{r}-0.094^{*} \\
(0.052)\end{array}$ & $\begin{array}{c}-0.063 \\
(0.089)\end{array}$ & $\begin{array}{r}-0.044 \\
(0.128)\end{array}$ \\
\hline $\mathrm{FS} \times \mathrm{FT}$ in 7 th Grade & $\begin{array}{l}0.124^{* * *} \\
(0.045)\end{array}$ & $\begin{array}{c}0.104^{* *} \\
(0.050)\end{array}$ & $\begin{array}{c}0.144^{* *} \\
(0.069)\end{array}$ & $\begin{array}{c}0.138^{* *} \\
(0.061)\end{array}$ & $\begin{array}{c}0.067 \\
(0.088)\end{array}$ & $\begin{array}{c}0.099 \\
(0.087)\end{array}$ \\
\hline Observations & 9,934 & 9,535 & 9,242 & 7,520 & 7,372 & 7,160 \\
\hline$R^{2}$ & 0.114 & 0.078 & 0.096 & 0.089 & 0.118 & 0.125 \\
\hline Dep. Var. Mean & 0.003 & 0.004 & 0.002 & 0.007 & 0.012 & 0.001 \\
\hline
\end{tabular}

Notes: Each column represents a separate regression, controlling for school by subject by ability group in 7 th grade fixed effects. Dependent variables are student behavior indices for 7 th through 12 th grades, constructed in a following way: first, we extract common variation, using principal component analysis, for each subject and each year, from the students response to 4 questions: whether he or she is focused in class, whether they participate in class, whether they do not skip homework assignment, and whether they review what they learned in class. The first component for each subject is regressed on student fixed effects; the residual is the student engagement index. Standard errors in parentheses are clustered at school level.

${ }^{*} p<.10,{ }^{* *} p<.05,{ }^{* * *} p<.01$

To complement the results on peer and teacher quality, we examine other measures of high school quality in Table 11. Column 1 shows the likelihood that the student attends a prestigious first-round high school, namely, an applicationonly high school, excluding non-elite vocational schools. The impact on the gender gap of having more female teachers is statistically insignificant. In Column 2 , there is a substantial but statistically insignificant effect on the likelihood of attending a high school in a different administrative district, which would reflect a willingness to incur greater costs to attend a preferred school. This effect is not entirely driven by students who attend first-round schools. Examining only those who attend second-round (lottery) high schools, the female student interaction with percent of 7 th grade female teachers is 0.138 (s.e. $=0.101$ ); once again, statistically insignificant but fairly sizable. This suggests even those female students with more female teachers who do not attend an application school are requesting higher-quality schools in the second-round lottery.

Column 3 shows the impacts on the percent of 11th grade students in a high school who achieved "Above Basic" performance in a particular subject on the National Assessment of Educational Achievement (NAEA) test; this indicates achievement above the median grade-level expectation. Importantly, these scores are for students one cohort above those in our sample. Column 4 shows results for students performing at the "Below Basic" level, below 20 percent of grade-level expectations. Finally, Column 5 shows the effects on the percent of students who are reported to the School Violence Committee, to which infractions against students both on and off school premises must be 
Table 11: Effects on High School Quality

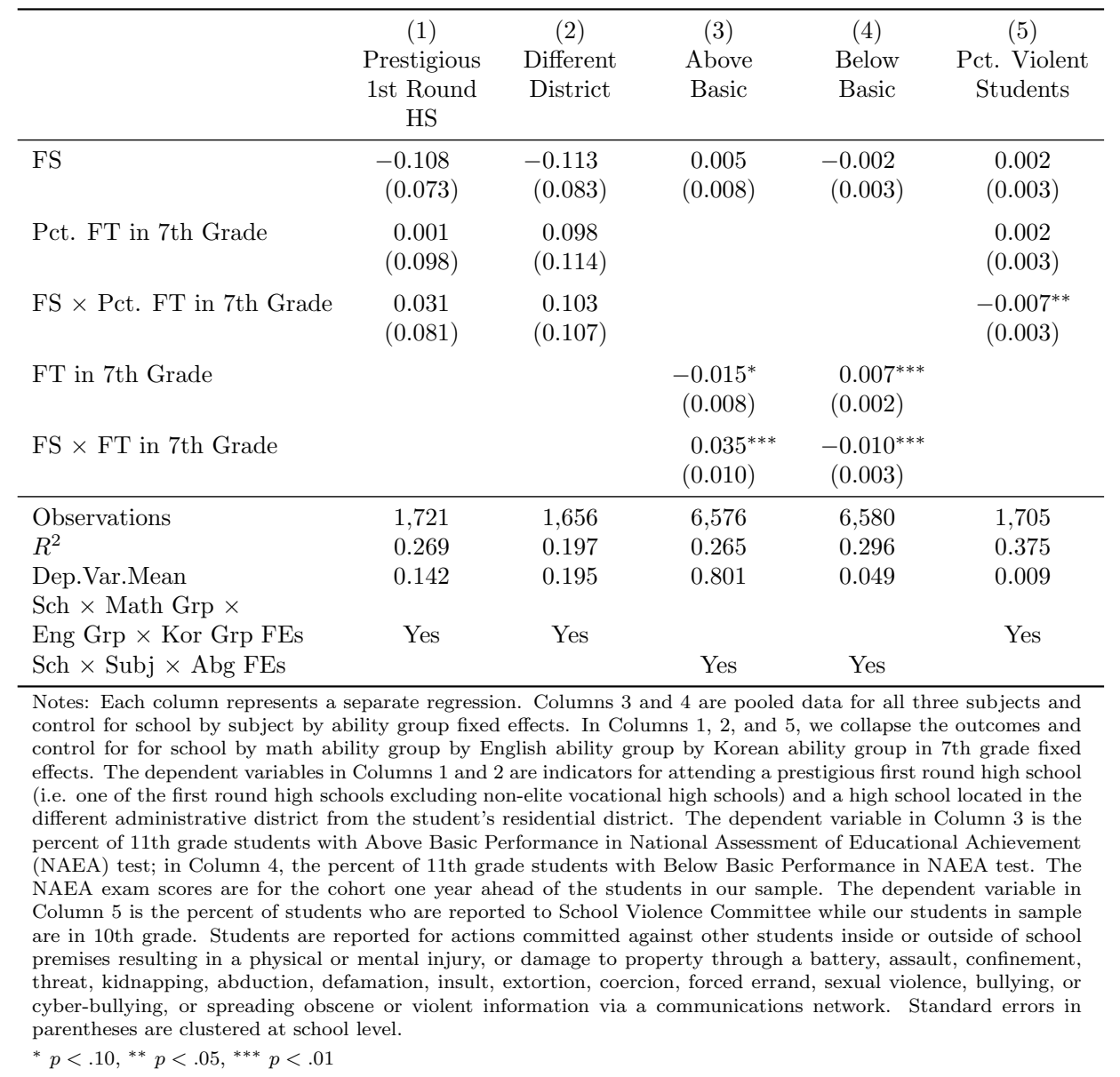


Table 12: Effects on Peer and Teacher Quality in Later Years

\begin{tabular}{|c|c|c|c|c|c|c|c|c|}
\hline \multirow[t]{2}{*}{ Dep. Var. $=$} & \multicolumn{4}{|c|}{ Peer Quality in } & \multicolumn{4}{|c|}{ Teacher Quality in } \\
\hline & $\begin{array}{c}\text { 8th } \\
\text { Grade } \\
(1)\end{array}$ & $\begin{array}{c}9 \text { th } \\
\text { Grade } \\
(2)\end{array}$ & $\begin{array}{c}10 \text { th } \\
\text { Grade } \\
(3)\end{array}$ & $\begin{array}{c}12 \text { th } \\
\text { Grade } \\
(4)\end{array}$ & $\begin{array}{c}8 \text { th } \\
\text { Grade } \\
(5)\end{array}$ & $\begin{array}{l}\text { 9th } \\
\text { Grade } \\
(6)\end{array}$ & $\begin{array}{l}10 \text { th } \\
\text { Grade } \\
(7)\end{array}$ & $\begin{array}{c}12 \text { th } \\
\text { Grade } \\
(8)\end{array}$ \\
\hline FS & $\begin{array}{c}-0.008 \\
(0.026)\end{array}$ & $\begin{array}{c}0.000 \\
(0.007)\end{array}$ & $\begin{array}{c}-0.001 \\
(0.041)\end{array}$ & $\begin{array}{c}0.022 \\
(0.042)\end{array}$ & $\begin{array}{c}0.002 \\
(0.013)\end{array}$ & $\begin{array}{c}0.011 \\
(0.010)\end{array}$ & $\begin{array}{c}0.018 \\
(0.034)\end{array}$ & $\begin{array}{c}-0.023 \\
(0.058)\end{array}$ \\
\hline FT in 7 th Grade & $\begin{array}{c}-0.022 \\
(0.021)\end{array}$ & $\begin{array}{c}0.005 \\
(0.009)\end{array}$ & $\begin{array}{c}-0.065 \\
(0.056)\end{array}$ & $\begin{array}{c}-0.086 \\
(0.053)\end{array}$ & $\begin{array}{c}0.013 \\
(0.017)\end{array}$ & $\begin{array}{c}-0.010 \\
(0.014)\end{array}$ & $\begin{array}{r}-0.007 \\
(0.037)\end{array}$ & $\begin{array}{r}-0.067 \\
(0.050)\end{array}$ \\
\hline $\mathrm{FS} \times \mathrm{FT}$ in 7 th Grade & $\begin{array}{c}-0.003 \\
(0.026)\end{array}$ & $\begin{array}{c}0.002 \\
(0.008)\end{array}$ & $\begin{array}{l}0.158^{* * *} \\
(0.046)\end{array}$ & $\begin{array}{l}0.127^{* * *} \\
(0.045)\end{array}$ & $\begin{array}{c}0.008 \\
(0.013)\end{array}$ & $\begin{array}{c}-0.006 \\
(0.012)\end{array}$ & $\begin{array}{l}0.096^{* *} \\
(0.041)\end{array}$ & $\begin{array}{c}0.116^{*} \\
(0.061)\end{array}$ \\
\hline $\begin{array}{l}\text { Observations } \\
R^{2}\end{array}$ & $\begin{array}{l}9,617 \\
0.659\end{array}$ & $\begin{array}{l}9,230 \\
0.817\end{array}$ & $\begin{array}{l}7,106 \\
0.215\end{array}$ & $\begin{array}{l}6,916 \\
0.160\end{array}$ & $\begin{array}{l}9,578 \\
0.430\end{array}$ & $\begin{array}{l}9,191 \\
0.509\end{array}$ & $\begin{array}{l}6,918 \\
0.314\end{array}$ & $\begin{array}{l}5,583 \\
0.176\end{array}$ \\
\hline \multicolumn{9}{|c|}{$\begin{array}{l}\text { Notes: Each column represents a separate regression, controlling for school by subject by ability group fixed effects. The } \\
\text { dependent variables in Columns } 1 \text { to } 4 \text { are peer quality measures and those in Columns } 5 \text { through } 8 \text { are teacher quality } \\
\text { measures. Peer quality is defined as the mean standardized test score in previous year, excluding a student's own score, for } \\
\text { each subject teacher. Teacher quality is the teacher fixed effect in } 8 \text { th, } 9 \text { th, } 10 \text { th, and } 12 \text { th grades, obtained as follows: for } \\
\text { each teacher } j \text { in } g \text { th grade (where } g=8,9 \text { and } 10 \text { ), take all the students whom teacher } j \text { teaches. Then, for each } g \text { th grade } \\
\text { student } i \text { under teacher } j \text {, calculate the leave-out means (excluding student } i \text { ) for }(g-1) \text { th and } g \text { th grade test scores. Next, } \\
\text { regress the leave-out mean for } g \text { th grade on that for }(g-1) \text { th grade and } g \text { th grade teacher fixed effects, controlling for } 7 \text { th } \\
\text { grade school } \times \text { subject } \times 7 \text { th grade ability group fixed effects. Standard errors in parentheses are clustered at school level. } \\
{ }^{*} p<.10,{ }^{* *} p<.05,{ }^{* * *} p<.01\end{array}$} \\
\hline
\end{tabular}

reported; these include violent acts but also bullying and cyber-bullying. Female students with a greater proportion of female teachers in 7th grade attend safer schools, though we note, at least based on official reports, schools in South Korea are extremely safe.

Taken together, these results indicate that the student-teacher gender interaction in middle school leads to greater engagement for female students with female teachers. Since the impact on attending application-only schools is fairly small, the primary channel for these results must be the choice set submitted by students for the second-round lottery. That is, exposure to female teachers in 7th grade leads female students to express a preference for higher-quality schools, even at a cost of greater travel time.

Finally, we turn to postsecondary outcomes. Our sample size is smaller due to the nature of this wave of the survey, which was conducted two months after these students left high school. Columns 1 through 3 show the results of the 7th grade teacher interaction variables on the probability of attending a university, a community college, or being employed, respectively. No meaningful patterns emerge; the coefficients are, for the most part, statistically insignificant. In Column 4, we examine the likelihood that students applied to a science, technology, engineering, or medical-sciences major conditional on attending a college or university; Column 5 narrows that definition by removing the traditional science fields. In both cases, female students with female math teachers in 7th grade were more likely to apply to those fields, though the effect is only statistically significant in Column 5, and is not distinguishable from a similarly positive interaction effect for having a female English teacher. For female students, the interaction effect with a female Korean teacher is large, negative, 
and statistically significant; having a female Korean teacher in 7th grade significantly reduces the likelihood that a female student will apply to a STEM major. Columns 6 and 7 condition on applying to a STEM or TEM field and examine the likelihood of being accepted; there are no significant impacts. The increase in applications coupled with little difference in acceptance rates suggests some uptick in female participation in these majors when they had a female 7th grade math teacher, though sample sizes are small and the estimates are fairly noisy.

Finally, Columns 7 and 8 use data from the 2014 Graduate Occupational Mobility Survey, which surveys recent college graduates 18 months after graduation. We match wage and employment information to major and examine whether majors chosen by students in our sample are more likely to lead to positive labor market outcomes. That is, these are not the actual outcomes for those in our data, who are just beginning their postsecondary education, but rather the projected outcomes. There are no impacts on the average wage, but female students with female math teachers in 7 th grade choose majors that have a statistically significant 3.8 percentage point higher employment rate shortly after graduation.

Taken together, our results suggest that there are substantial impacts on the secondary-school performance for female students with female teachers, particularly in STEM subjects. These are driven by changes in attitudes, aspirations, and choices, particularly in terms of course-taking and high school quality. Given the nature of the South Korean education system, the large improvements in academic performance, increase in positive attitudes towards STEM fields, and increases in propensity to take STEM courses are necessary to see a greater likelihood of majoring in STEM fields in college by female students. However, our results are much more mixed for realized postsecondary outcomes, suggesting that these improvements are not sufficient to yield meaningful changes in actual outcomes.

\section{Conclusions}

Our study shows that female students' pairing with female teachers at a formative age - middle school - increases standardized test scores well into high school, the likelihood of advanced course-taking and making plans for postsecondary attendance, and, specifically for those with female math teachers, both studying STEM and aspirations to do so in college. We show that persistent student engagement and increased ambition in choosing high schools of higher quality explain why there is little fade-out of these impacts. It is important to note that there are, at times, partially offsetting negative effects on academic outcomes for boys from a shift to female teachers. Overall, these findings shed light on the importance of teacher-student gender matches in future policies to close the gender gap, especially in STEM fields. However, results on postsecondary outcomes suggest that interventions in secondary school may not be sufficient to substantially increase participation at that level. 
Table 13: 7th Grade Teacher Effects on Postsecondary Outcomes

\begin{tabular}{|c|c|c|c|c|c|c|c|c|c|}
\hline & $\begin{array}{c}(1) \\
\text { Univ }\end{array}$ & $\begin{array}{c}(2) \\
\text { Cmnty } \\
\text { Clg }\end{array}$ & $\begin{array}{c}(3) \\
\text { Employed }\end{array}$ & $\begin{array}{c}(4) \\
\text { STEM } \\
\text { Applied }\end{array}$ & $\begin{array}{c}(5) \\
\text { TEM } \\
\text { Applied }\end{array}$ & $\begin{array}{c}(6) \\
\text { STEM } \\
\text { Acpt }\end{array}$ & $\begin{array}{c}(7) \\
\text { TEM } \\
\text { Acpt }\end{array}$ & $\begin{array}{c}(8) \\
\text { Log } \\
\text { Wage }\end{array}$ & $\begin{array}{l}(9) \\
\text { Employment } \\
\text { Rate }\end{array}$ \\
\hline FS & $\begin{array}{c}-0.081 \\
(0.124)\end{array}$ & $\begin{array}{c}0.035 \\
(0.074)\end{array}$ & $\begin{array}{c}0.051 \\
(0.056)\end{array}$ & $\begin{array}{c}-0.115 \\
(0.250)\end{array}$ & $\begin{array}{c}-0.145 \\
(0.227)\end{array}$ & $\begin{array}{c}-0.166 \\
(0.335)\end{array}$ & $\begin{array}{c}0.167 \\
(0.415)\end{array}$ & $\begin{array}{c}-0.031 \\
(0.054)\end{array}$ & $\begin{array}{c}0.014 \\
(0.027)\end{array}$ \\
\hline FT in math & $\begin{array}{c}-0.065 \\
(0.086)\end{array}$ & $\begin{array}{c}0.017 \\
(0.068)\end{array}$ & $\begin{array}{c}-0.025 \\
(0.034)\end{array}$ & $\begin{array}{c}0.095 \\
(0.075)\end{array}$ & $\begin{array}{r}-0.101^{*} \\
(0.058)\end{array}$ & $\begin{array}{c}-0.123 \\
(0.112)\end{array}$ & $\begin{array}{c}0.007 \\
(0.144)\end{array}$ & $\begin{array}{c}-0.030 \\
(0.025)\end{array}$ & $\begin{array}{c}-0.016 \\
(0.014)\end{array}$ \\
\hline FT in Eng & $\begin{array}{c}0.041 \\
(0.135)\end{array}$ & $\begin{array}{c}0.061 \\
(0.135)\end{array}$ & $\begin{array}{r}-0.068 \\
(0.048)\end{array}$ & $\begin{array}{c}-0.071 \\
(0.079)\end{array}$ & $\begin{array}{r}-0.147 \\
(0.092)\end{array}$ & $\begin{array}{c}0.132 \\
(0.120)\end{array}$ & $\begin{array}{c}-0.073 \\
(0.071)\end{array}$ & $\begin{array}{c}-0.022 \\
(0.042)\end{array}$ & $\begin{array}{c}0.031 \\
(0.046)\end{array}$ \\
\hline FT in Kor & $\begin{array}{l}-0.206^{* *} \\
(0.080)\end{array}$ & $\begin{array}{c}0.028 \\
(0.044)\end{array}$ & $\begin{array}{c}0.059 \\
(0.060)\end{array}$ & $\begin{array}{r}0.240^{*} \\
(0.134)\end{array}$ & $\begin{array}{c}0.164 \\
(0.102)\end{array}$ & $\begin{array}{c}-0.158 \\
(0.114)\end{array}$ & $\begin{array}{c}0.086 \\
(0.176)\end{array}$ & $\begin{array}{c}0.027 \\
(0.027)\end{array}$ & $\begin{array}{r}0.021^{*} \\
(0.012)\end{array}$ \\
\hline $\mathrm{FS} \times \mathrm{FT}$ in math & $\begin{array}{c}-0.041 \\
(0.090)\end{array}$ & $\begin{array}{c}0.011 \\
(0.059)\end{array}$ & $\begin{array}{c}0.036 \\
(0.037)\end{array}$ & $\begin{array}{c}0.086 \\
(0.095)\end{array}$ & $\begin{array}{l}0.167^{* *} \\
(0.078)\end{array}$ & $\begin{array}{c}-0.060 \\
(0.123)\end{array}$ & $\begin{array}{c}-0.011 \\
(0.170)\end{array}$ & $\begin{array}{c}0.026 \\
(0.034)\end{array}$ & $\begin{array}{l}0.038^{* *} \\
(0.017)\end{array}$ \\
\hline $\mathrm{FS} \times \mathrm{FT}$ in Eng & $\begin{array}{c}0.000 \\
(0.112)\end{array}$ & $\begin{array}{c}0.021 \\
(0.044)\end{array}$ & $\begin{array}{r}-0.006 \\
(0.045)\end{array}$ & $\begin{array}{c}0.103 \\
(0.151)\end{array}$ & $\begin{array}{c}0.193 \\
(0.152)\end{array}$ & $\begin{array}{c}-0.030 \\
(0.203)\end{array}$ & $\begin{array}{c}-0.215 \\
(0.303)\end{array}$ & $\begin{array}{c}-0.003 \\
(0.041)\end{array}$ & $\begin{array}{c}-0.016 \\
(0.015)\end{array}$ \\
\hline $\mathrm{FS} \times \mathrm{FT}$ in $\mathrm{Kor}$ & $\begin{array}{c}0.155 \\
(0.110)\end{array}$ & $\begin{array}{c}-0.056 \\
(0.071)\end{array}$ & $\begin{array}{r}-0.064^{*} \\
(0.038)\end{array}$ & $\begin{array}{r}-0.285^{*} \\
(0.153)\end{array}$ & $\begin{array}{l}-0.397^{* * *} \\
(0.124)\end{array}$ & $\begin{array}{r}0.402^{*} \\
(0.221)\end{array}$ & $\begin{array}{c}0.189 \\
(0.195)\end{array}$ & $\begin{array}{c}-0.051 \\
(0.046)\end{array}$ & $\begin{array}{c}-0.028 \\
(0.028)\end{array}$ \\
\hline Observations & 1,094 & 1,094 & 1,094 & 751 & 751 & 422 & 319 & 704 & 704 \\
\hline$R^{2}$ & 0.266 & 0.312 & 0.357 & 0.426 & 0.436 & 0.504 & 0.591 & 0.391 & 0.280 \\
\hline Dep. Var. Mean & 0.418 & 0.237 & 0.068 & 0.449 & 0.330 & 0.770 & 0.781 & 5.272 & 0.744 \\
\hline \multicolumn{10}{|c|}{$\begin{array}{l}\text { Notes: Each column represents a separate regression. We control for school by math group by English language group by Korean language } \\
\text { group in } 7 \text { th grade by college type FEs for Columns } 4 \text { through } 7 \text { and school by math group by English language group by Korean language } \\
\text { group in } 7 \text { th grade FEs for the rest of the columns. Dependent variables in Columns } 1 \text { through } 7 \text { are, respectively, indicator variables for } \\
\text { (1) being accepted by a university, (2) being accepted by a community college, (3) being employed, (4) applying for a STEM major, (5) } \\
\text { applying for a TEM major, }(6) \text { being accepted in a STEM major, and }(7) \text { being accepted in a TEM major. Dependent variables in Column } \\
8 \text { and } 9 \text { are the log of average wage and the employment rate for the student's major. In Columns } 4 \text { and } 5 \text {, we exclude the students who } \\
\text { report that their major was not their top choice. In Columns } 6 \text { and } 7 \text {, the regression is conditional on applying for a STEM and a TEM } \\
\text { major, respectively. Standard errors in parentheses are clustered at school level. } \\
{ }^{*} p<.10,{ }^{* *} p<.05,{ }^{* * *} p<.01\end{array}$} \\
\hline
\end{tabular}




\section{References}

Antecol, Heather, Ozkan Eren, and Serkan Ozbeklik. 2015. "The Effect of Teacher Gender on Student Achievement in Primary School." Journal of Labor Economics, 33(1): 63-89.

Berenbaum, Sheri A., Carol Lynn Martin, and Diane N. Ruble. 2008. "Gender Development." Child and Adolescent Development: An Advanced Course, 647-695.

Byun, Sooyong, and Kyungkeun Kim. 2010. "Educational inequality in South Korea: The widening socioeconomic gap in student achievement." Research in Sociology of Education, 17(155-182).

Carlsson, Magnus, Gordon B Dahl, Björn Öckert, and Dan-Olof Rooth. 2015. "The effect of schooling on cognitive skills." Review of Economics and Statistics, 97(3): 533-547.

Carrell, Scott E., and James E. West. 2010. "Does Professor Quality Matter? Evidence from Random Assignment of Students to Professors." Economics of Education Review, 118(3): 409-432.

Carrell, Scott E., Marianne E. Page, and James E. West. 2010. "Sex and Science: How Professor Gender Perpetuates the Gender Gap." Quarterly Journal of Economics, 125(3): 1101-1144.

Cho, Insook. 2012. "The Effect of Teacher Student Gender Matching: Evidence from OECD Countries." Economics of Education Review, 31(3): 54-67.

Dee, Thomas S. 2007. "Teachers and the gender gaps in student achievement." Journal of Human Resources, 42(3): 528-554.

Elbe, Alex, and Feng Hu. 2017. "Stereotypes, Role Models, and the Formation of Beliefs."

Gershenson, Seth, Cassandra Hart, Cassandra Lindsay, and Nicholas W. Papageorge. 2017. "The Long-run Impacts of Same-Race Teachers."

Gershenson, Seth, Stephen B. Holt, and Nicholas W. Papageorge. 2016. "Who believes in me? The effect of student-teacher demographic match on teacher expectations." Economics of Education Review, 52: 209-224.

Good, Phillip I. 2006. Resampling Methods: A Practical Guide to Data Analysis. 3rd ed. Boston: Birkhäuser.

Holmlund, Helena, and Krister Sund. 2008. "Is the Gender Gap in School Performance Affected by the Sex of the Teacher?" Labour Economics, 15(1): 37-53. 
Jacob, Brian A, Lars Lefgren, and David P Sims. 2010. "The persistence of teacher-induced learning." Journal of Human resources, 45(4): 915-943.

Kang, Changhui. 2007. "Classroom peer effects and academic achievement: Quasi-randomization evidence from South Korea." Journal of Urban Economics, 61(3): 458-495.

Kofoed, Michael S., and Elizabeth McGovney. 2017. "The Effect of SameGender and Same-Race Role Models on Occupation Choice: Evidence from Randomly Assigned Mentors at West Point." Journal of Human Resources.

Korea Legislation Research Institute. 2011. "Enforcement Decree of the Elementary and Secondary Eduation Act, Article 68 (Methods for Entering Middle Schools)." Presidential Decree No.22712.

Lavy, Victor, and Edith Sand. 2015. "On The Origins of Gender Human Capital Gaps: Short and Long Term Consequences of Teachers Stereotypical Biases." NBER Working Paper No. 20909.

Lehmann, Erich L., and Joseph P. Romano. 2005. Testing Statistical Hypotheses (Springer Texts in Statistics). . 3rd ed., Springer.

Leslie, Sarah-Jane, Andrei Cimpian, Meredith Meyer, and Edward Freeland. 2015. "Expectations of brilliance underlie gender distributions across academic disciplines." Science, 347(6219): 262-265.

Lim, Jaegeum, and Jonathan Meer. forthcoming. "The Impact of TeacherStudent Gender Matches: Random Assignment Evidence from South Korea." Journal of Human Resources.

Muralidharan, Karthik, and Ketki Sheth. 2016. "Bridging Education Gender Gaps in Developing Countries: The Role of Female Teachers." Journal of Human Resources, 51(2): 269-97.

Seoul Metropolitan Office of Education. 2012. "Announcement on High School Admissions Plan for 2013 School Year." SMOE Announcement No.2012-51.

Spencer, Steven J., Claude M. Steele, and Diane M. Quinn. 1999. "Stereotype threat and women's math performance." Journal of experimental social psychology, 35(1): 4-28. 